Original Paper http://ajol.info/index.php/ijbcs http://indexmedicus.afro.who.int

\title{
Ultraviolet spectroscopic evaluation of bioactive saponin fraction from the aqueous extract of Vernonia amygdalina [Esteraeceae] leaf
}

\author{
Paul Chukwuemeka ADIUKWU ${ }^{1 *}$, Martina BONSU ${ }^{1}$, Inemesit OKON-BEN ${ }^{1}$, \\ Paul PEPRAH ${ }^{1}$, Paapa MENSAH-KANE ${ }^{1}$, Jonathan JATO ${ }^{1}$ and Grace NAMBATYA ${ }^{2}$ \\ ${ }^{I}$ School of Pharmacy, University of Health \& Allied Science, PMB 31 Ho, Volta Region, Ghana. \\ ${ }^{2}$ Natural Chemotherapeutic Research Laboratories, P.O Box 4864 Kampala, Uganda. \\ ${ }^{3}$ Faculty of Medicine, Mbarara University of Science \& Technology, P.O. Box 1410 Mbarara, Uganda. \\ "Corresponding author; E-mail: pcadiukwu@uhas.edu.gh; Tel: +233507616339
}

\begin{abstract}
The use of herbal therapy is a common practice in Africa. One of the commonly used herbs is Vernonia amygdalina. Processing of the plant for use leads to the loss of phytochemical principles like saponin which has been shown to possess bioactivity. This study was to evaluate and characterize the saponin principles, using chromatographic and spectroscopic techniques. Standard antipyretic study procedure using Saccharomyces cerevisiae induced pyrexia in rats was used for the evaluation of the herbal aqueous extract, as well as, the crude saponin and its chromatographic fraction. The separation and chromatogram development of resulting pure saponin components was carried out using a HPLC with UV-vis detection at $365 \mathrm{~nm}$. Data for the antipyretic study agrees with previous bioactivity report for the saponin. Chromatographic and spectroscopic evaluation indicated the presence of three pure saponin components at retention times of $7.78 \pm 0.19,8.76 \pm$ 0.16 and $13.54 \pm 0.87$ minutes, in the fractionate. Finding suggests that the pure components are individual or collective contributors to the bioactivity of the crude saponin and fractionate. Further bioactivity probe of the pure components will aid good understanding and use of the herbal medication.
\end{abstract}

(C) 2017 International Formulae Group. All rights reserved.

Keywords: Chromatographic, detection, pure components, bioactivity, rats.

\section{INTRODUCTION}

The use of herbal preparations as a form of therapy dates back to many years ago. Their effectiveness in general management of wellbeing has been attributed to the various phytochemical constituents commonly referred to as secondary metabolites. These compounds as used in phytomedicine can be considered to be the prime foundation of the contemporary allopathic medicines today.

Some vegetables commonly eaten as food have been shown to be beneficial in herbal therapy (Patrice et al., 2010). Vernonia amygdalina commonly referred to as "bitter leaf" can be considered to be one of the numerous medicinal vegetables widely used locally in Ghana, Nigeria and other African countries. It grows in a range of ecological zones in Africa and the Arabian Peninsula. Some of the local names associated with this herb include "omubirizi" or "omululuza" (West and Central Uganda); "olusia" (Luo, Kenya); or "ewuro", "etidot" and "olugbo" (Southern Nigeria) (Nwaoguikpe, 2010). The 
leaf is used for both its nutritional and therapeutic benefits (Izevbigie, 2005). In Southern Ethiopia, dairy farmers feed the leaf to their stock during the dry period, after boiling to decrease the bitter taste. Prior study showed that feed intake, body weight gain and feed efficiency were not affected when the leaf was used to replace $300 \mathrm{~g} / \mathrm{kg}$ of maizebased diet fed to broilers (Bonsi et al., 1995).

Previous studies have identified a number of bioactive phytochemicals in the leaf extract of this plant (Izevbigie, 2005). The bitter taste of the leaf has been attributed to the presence of anti-nutritive principles like saponins, alkaloids, tannins and glycosides (Owoeye et al., 2010). As a consequence, the processing of the leaf for human consumption which involves soaking and washing in warm water has been targeted at reducing these bitter tasting principles (Ridout et al., 1991; Güçlü-Ustündağ and Mazza, 2007).

Saponin which is one of these bitter tasting principles is widely distributed in plants (Izevbigie, 2005). It is a glycoside which is characterized by the number of sugar chains attached to the triterpene or steroid aglycone backbone called sapogenin. Due to this bitter and unpleasant taste of saponins, their use in food and phytomedicine has been highly limited (Izevbigie, 2005).

Evidence has shown that the main dietary sources of saponins are the dicotyledon like legumes while the main nonfood sources used in health and industrial applications include the soap bark tree, Medicago sativa, Aesculus hippocastanum and Glycyrrhiza glabra (Güçlü-Ustündağ and Mazza, 2007). In recent time, saponins have come into renewed focus due to increasing evidence of their health benefits (Shi et al., 2004). Prior studies have highlighted the contributions of some saponin containing foodstuffs to health (Liu and Henkel, 2002). However, a major limitation to these studies is the inability to sufficiently validate obtained data. Little has been done in isolating and evaluating of specific identifiable bioactive principle(s).
A Previous study has identified the crude saponin obtained from the aqueous extract of Vernonia amygdalina leaf to possess antipyretic properties (Adiukwu et al., 2013). Therefore, the objective of this study was to investigate the column fractionate and characterize the saponin principles of the leaf aqueous extract, using spectroscopic and chromatographic techniques.

\section{MATERIALS AND METHODS \\ Chemicals, drugs and test agents:}

Analytical grades of methanol, nbutan-1-ol, diethyl ether, chloroform, acetone, and xylene from BDH, Uganda and acetic acid (Sigma-Aldrich, Germany) were used. Active dry Saccharomyces cerevisiae: brewer's yeast (Griffchem ${ }^{\circledR}$ ) was used to induce pyrexia in the antipyretic study. A dose of $300 \mathrm{mg} / \mathrm{kg}$ acetylsalicylic acid (ASA) (Pinewood, Caprin ${ }^{\circledR}$ ) as reference standard, 5 $\mathrm{ml} / \mathrm{kg}$ normal saline solution (Albert David, India) as placebo, $V$. amygdalina leaf aqueous extract as test sample 1, crude saponin as test sample 2 and Vernonia amygdalina saponin fraction B (Va-SB ) as test sample 3, were used in the animal study.

\section{Plant material and extraction}

The fresh leaves of Vernonia amygdalina identified by a botanist were collected in the morning, between June and July (raining season) in south-western Uganda region. Specimens were retained with voucher number 16-20 in the Pharmacy Department, Faculty of Medicine, Mbarara University of Science and Technology. The leaves were shade air-dried and ground into a coarse powder that was sieved to $2000 \mathrm{~g}$ fine powder. The moistened powder was allowed to stand for 15 minutes before maceration for three hours in warm $\left(\leq 80{ }^{\circ} \mathrm{C}\right)$ distilled water at a modified ratio of $131 \mathrm{~g}$ to 9.0 liters with intermittent shaking (Singh, 2008). The obtained infusion was filtered through filterpaper while warm. The filtrate was further filtered using Buckner filter assemblage (aided by a suction pump) and subsequently 
evaporated to dryness in an oven (at $\leq 80{ }^{\circ} \mathrm{C}$ ). The total amount of yield (leaf residue) obtained was $18 \%$. This was stored in a desiccator at room temperature $\left(25^{\circ} \mathrm{C}\right)$.

\section{Phytochemical screening}

Preliminary screening of the aqueous extract for phytochemicals was carried out using standard procedures (Harborne, 1973). Test procedures carried out were foaming assay for saponins; dragendorff's test for Alkaloids; baljet test for sophisticated lactones; liebermann-burchard test for triterpenes and steroids; fehling test for reducing sugars; ninhydrine test for amino acids; shinoda assay for flavonoids; borntragers test for quinines; salkowski test for terpenoids; ferric chloride test for tannins; and kedde's assay for cardiotonic glycosides.

\section{Isolation and fractionation Isolation}

The liquid-liquid extraction technique as described by Obadoni and Ochuko (2001) was adopted for the isolation of the crude saponin. A forty millimetre solution was prepared in distilled water using $20 \mathrm{~g}$ of the dried aqueous extract of $V$. amygdalina leaf. This was extracted thrice with $20 \mathrm{ml}$ diethyl ether. The diethyl ether layer was discarded and the retained aqueous layer extracted further with $60 \mathrm{ml} \mathrm{n}$-butan-1-ol (four times). The n-butan-1-ol extracts were bulked together and washed four times using $10 \mathrm{ml}$ of five percent $\mathrm{NaCl}$. The washed extract was concentrated at $<80{ }^{\circ} \mathrm{C}$ in an oven and air dried at room temperature to yield $1.81 \mathrm{~g}$ $(9.1 \% \mathrm{w} / \mathrm{w})$ of crude saponin residue. The residue was screened for saponin using the foaming test (Harborne, 1973).

\section{Flash column chromatographic fractionation}

Procedure as described by Adiukwu et al. (2013) was adopted for this study. The crude saponin dissolved in methanol was adsorbed onto a TLC grade silica gel (CSI 010, Unilab) at a ratio of two to five and dried in an oven at $\leq 80{ }^{\circ} \mathrm{C}$ to produce a $21 \mathrm{~g}$ free flowing powder. The powder was loaded and fractionated on a silica gel (May \& Baker Dagenham, England: 0.2-0.5 mm, pore size 40 angstrom, 30-70 mesh) containing flash column (Stil et al., 1978). The column was eluted with a gradient mobile phase solvent system of increasing polarity starting with xylene; combination of chloroform and methanol (one to one); and methanol, in multiples of $100 \mathrm{ml}$. An air pump (Merck, Germany) was used to facilitate the rate of elution. Each $10 \mathrm{ml}$ effluent collected was profiled using TLC with a mobile phase system of acetone, chloroform and methanol (at a ratio of one to four to two) (Hostettmann and Marston, 1986). Spots were located using saturated iodine chamber. Effluents with similar profile were combined together, concentrated over a water bath and allowed to evaporate to dryness at room temperature. This resulted in 2 fractions: Vernonia amygdalina saponin fraction A (Va-SA) 0.932 $\mathrm{g}$, eluted with chloroform/methanol and Vernonia amygdalina saponin fraction B (VaSB) $1.35 \mathrm{~g}$, eluted with methanol. A preliminary screening of both fractions using foaming test was conducted (Harborne, 1973). $\mathrm{Va}-\mathrm{SB}$ was positive and was preserved in a desiccator for further use.

\section{Animals}

Twenty-five Wistar rats weighing between 120-200 $\mathrm{g}$ of both sexes were selected for the different antipyretic evaluations. The animals were placed in standard cages where they were maintained on standard animal pellets (Nuvita Feeds Ltd., Kampala) and water ad libitum. The rats for antipyretic evaluation were selected based on their measured basal anal temperature $(\leq 37$ ${ }^{\circ} \mathrm{C}$ ) using a thermistor probe (with a resolution of $5.0 \times 10^{-4}$ and accurate to $1.0 \times 10^{-3}{ }^{\circ} \mathrm{C}$ ), and also achieving a minimum of $0.1{ }^{\circ} \mathrm{C}$ increase in anal temperature in response to 10 $\mathrm{ml} / \mathrm{kg}$ intra-peritoneal (i.p) administered 15\% $\mathrm{w} / \mathrm{v}$ Saccharomyces cerevisiae. The animals 
were randomly divided into five groups of five animals each and fasted over-night.

National Institute of Health (NIH) guide for the care and use of laboratory animals as approved by the Institutional Ethical Committee was adopted for the animal protocol in this study (NIH, 1978).

\section{Preparation and administration of drug}

All the reference standard and test samples were prepared using sterile normal saline solution which also, served as placebo in the antipyretic study. Oral administration was carried out using a cannula-syringe assemblage.

\section{Antipyretic study}

Standard procedure as described by previous study was adopted (Okokon and Onah, 2004). Wistar rats earlier selected and induced pyrexia as described above, were randomly divided into five groups of five animals each. The animals were allowed to starve overnight in their respective cages. Twenty hours after the administration of Saccharomyces cerevisae solution, the anal temperature of each animal in their respective group was measured. Oral administration of normal saline to group one, ASA to group two and aqueous extracts $(400 \mathrm{mg} / \mathrm{kg}, 600 \mathrm{mg} / \mathrm{kg}$ or $800 \mathrm{mg} / \mathrm{kg}$ ) to groups three to five was immediately carried out after the anal temperature measurement. Four hours after the administration of the dose, the anal temperature of each animal was measured again.

Similar antipyretic evaluation procedure was adopted for the crude saponin using three dose levels: 200, 400 and 600 $\mathrm{mg} / \mathrm{kg}$; and for the chromatographic fraction Va-SB 200, 300 and $400 \mathrm{mg} / \mathrm{kg}$. Doses employed in this study were based on prior study of crude saponin content in $V$. amygdalina leaf (Adiukwu et al., 2011).

\section{HPLC-UV spectroscopic evaluation Va-SB sample preparation}

Standard method as described by Hostettmann and Marston (1986) was adhered to in this procedure. Sample was freshly prepared by dissolving $\mathrm{Va}-\mathrm{SB}$ in $80 \%$ methanol and sonicated to form a $5 \times 10^{-2} \mathrm{~g} / \mathrm{ml}$ solution. This was filtered with a membrane filter of $0.45 \mu \mathrm{m}$ pore size and $0.25 \mathrm{~mm}$ diameter (coat number: 08020177). The filtrate was kept in an ultra-low temperature freezer for subsequent use.

\section{Mobile phase}

Following a prior preliminary TLC evaluation of the Va-SB fraction, a linear gradient mobile phase of methanol and water was adopted for this study. The freshly prepared mobile phases were 100, 70, 60, 40, 20 and $0 \%$ methanol solutions. Each of the solutions were sonicated for 6 minutes and mounted with their respective sample bottle.

\section{Stationary Phas}

Using a 2.3 x $60 \mathrm{~mm}$ diameter and 5 $\mu \mathrm{m}$ particle size reverse phase $\mathrm{C}_{18}$ column (Agilent $^{\circledR}$ PN 880975-905, Germany) at a pressure between 162 and $171 \mathrm{Kgf}$ with a flow rate of $0.2 \mathrm{ml} / \mathrm{minute}$, the stationary phase was conditioned (base line). The baseline determination was performed using a double beam UV-vis detector HPLC equipment (Shimadzu 1601, Germany), before subsequent chromatograms of the mobile phases were developed.

\section{Chromatogram development:}

The sample prepared as above was placed in the oven at $25{ }^{\circ} \mathrm{C}$ using sample vials of $15 \mu \mathrm{ml}$. After a prior conditioning of the stationary phase as described above, the chromatogram for the various mobile phases at a run time of 25 minutes were developed in accordance with the standard method (Stil et al., 1978).

System optimization and $\boldsymbol{U}$-determination Using $70 \%$ methanol as the mobile phase with the best resolution and the stationary phase as described above, the system was optimized at a UV-vis detection of $365 \mathrm{~nm}$. The retention time and chromatogram 
of the pure components were determined by the aid of the double beam UV-vis detector (Cairns, 2002).

\section{Statistical analysis}

Data and calculations were based on the numerical expression of mean \pm SEM. Analysis of variance (ANOVA) was used for the analysis of values within groups and student T-test, for data between groups. $P \leq$ 0.05 was taken as level of significance in all cases where applied.

\section{RESULTS}

\section{Phytochemical screening}

Standard test for phytochemical constituents revealed the presence of saponins, alkaloids, sophisticated lactones, triterpenoids, reducing sugars, amino acids, flavonoids, terpenoids, tannins and cardiotonic glycosides but absence of quinine.

\section{Antipyretic study}

The antipyretic study showed a dose dependent response with the extract (Table 1), crude saponin (Table 2) and Va-SB fraction (Table 3). Statistical analysis using ANOVA indicated no significant $(P \leq 0.05)$ difference in the yeast induced anal temperature within and among groups. T-test analysis indicated significant $(P \leq 0.05)$ dose induced anal temperature decrease for all the test samples in the different evaluations. However, at similar dose levels of 400 and $200 \mathrm{mg} / \mathrm{kg}$ crude saponin produced higher anal temperature decrease than the Va-SB fraction.

\section{HPLC-UV spectroscopic determination}

Obtained data as shown by the chromatogram (Figure 1) indicated that the Va-SB fraction constitute of three pure principles: $\mathrm{Va}-\mathrm{SB}_{1}, \mathrm{Va}-\mathrm{SB}_{2}$, and $\mathrm{Va}-\mathrm{SB}_{3}$ at a ratio of $24: 24: 1$ as indicated by their areas of absorption. Because of the nature of the stationary phase, the obtained retention times suggests $\mathrm{Va}-\mathrm{SB}_{1}$ to be the most polar among the pure components.

Table 1: Effect of the aqueous extract on the anal temperature in rats 4 hrs after administration.

\begin{tabular}{|c|c|c|c|c|}
\hline \multirow{2}{*}{ Group } & \multirow{2}{*}{ Dose } & \multicolumn{2}{|c|}{$\begin{array}{l}20 \text { hrs after yeast administration, } \\
\text { the anal temp. }{ }^{\circ} \mathrm{C} \text { readings are }\end{array}$} & \multirow{2}{*}{$\begin{array}{l}\text { Dose induced anal } \\
\text { temp. }{ }^{\circ} \mathrm{C} \text { decrease }\end{array}$} \\
\hline & & $\begin{array}{l}0 \text { hrs (after } \\
\text { dose admin.) }\end{array}$ & $\begin{array}{l}4 \text { hrs (after dose } \\
\text { admin.) }\end{array}$ & \\
\hline Placebo & $\begin{array}{l}\text { Normal saline } 5 \\
\mathrm{ml} / \mathrm{kg}\end{array}$ & $39.02 \pm 0.11$ & $39.01 \pm 0.11$ & $0.02 \pm 0.02$ \\
\hline Standard & ASA 300 mg/kg & $39.12 \pm 0.10$ & $38.97 \pm 0.07$ & $\begin{array}{c}* 0.15 \pm 0.04 \\
\left(P=1.65 \times 10^{-6}\right)\end{array}$ \\
\hline Test 1 & $\begin{array}{c}\text { Extract } 400 \\
\mathrm{mg} / \mathrm{kg}\end{array}$ & $39.21 \pm 0.18$ & $38.66 \pm 0.17$ & $\begin{array}{c}* 0.53 \pm 0.03 \\
\left(P=4.3 \times 10^{-10}\right)\end{array}$ \\
\hline Test 2 & $\begin{array}{c}\text { Extract } 600 \\
\mathrm{mg} / \mathrm{kg}\end{array}$ & $39.09 \pm 0.20$ & $38.18 \pm 0.15$ & $\begin{array}{c}* 0.98 \pm 0.07 \\
\left(P=6.8 \times 10^{-} 6\right)\end{array}$ \\
\hline Test 3 & $\begin{array}{c}\text { Extract } 800 \\
\mathrm{mg} / \mathrm{kg}\end{array}$ & $39.08 \pm 0.13$ & $37.58 \pm 0.19$ & $\begin{array}{l}* 1.50 \pm 0.20 \\
\left.P=6.7 \times 10^{-7}\right)\end{array}$ \\
\hline
\end{tabular}

Data are mean \pm SEM (standard error of mean) value $(n=5) . *$ Significantly $(P \leq 0.05)$ different from placebo. 
Table 2: Effect of the crude saponin on the anal temperature in rats $4 \mathrm{hrs}$ after administration.

\begin{tabular}{|c|c|c|c|c|}
\hline \multirow{2}{*}{ Group } & \multirow{2}{*}{ Dose } & \multicolumn{2}{|c|}{$\begin{array}{l}20 \text { hrs after yeast administration, } \\
\text { the anal temp. }{ }^{\circ} \mathrm{C} \text { readings are }\end{array}$} & \multirow{2}{*}{$\begin{array}{c}\text { Dose induced } \\
\text { anal temp. }{ }^{\circ} \mathrm{C} \\
\text { decrease }\end{array}$} \\
\hline & & $\begin{array}{l}0 \text { hrs (after } \\
\text { dose admin.) }\end{array}$ & $\begin{array}{l}4 \text { hrs (after dose } \\
\text { admin.) }\end{array}$ & \\
\hline Placebo & Normal saline $5 \mathrm{ml} / \mathrm{kg}$ & $39.054 \pm 0.12$ & $39.04 \pm 0.11$ & $0.014 \pm 0.02$ \\
\hline Standard & ASA $300 \mathrm{mg} / \mathrm{kg}$ & $39.10 \pm 0.11$ & $38.95 \pm 0.08$ & $\begin{array}{c}* 0.15 \pm 0.04 \\
\left(P=3.95 \times 10^{-3}\right)\end{array}$ \\
\hline Test & Crude saponin $200 \mathrm{mg} / \mathrm{kg}$ & $38.75 \pm 0.25$ & $38.62 \pm 0.24$ & $\begin{array}{c}* 0.14 \pm 0.03 \\
\left(P=2.4 \times 10^{-4}\right)\end{array}$ \\
\hline Test & Crude saponin $400 \mathrm{mg} / \mathrm{kg}$ & $38.78 \pm 0.19$ & $38.49 \pm 0.18$ & $\begin{array}{l}* 0.29 \pm 0.02 \\
\left(P=1.2 \times 10^{-4}\right)\end{array}$ \\
\hline Test & Crude saponin $600 \mathrm{mg} / \mathrm{kg}$ & $38.66 \pm 0.11$ & $38.29 \pm 0.11$ & $\begin{array}{c}* 0.39 \pm 0.01 \\
\left(P=1.06 \times 10^{-5}\right)\end{array}$ \\
\hline
\end{tabular}

Table 3: Effect of the Vernonia amygdalina chromatographic fraction, $V a-\mathrm{SB}$ on the anal temperature in rats $4 \mathrm{hrs}$ after administration.

\begin{tabular}{|c|c|c|c|c|}
\hline \multirow{2}{*}{ Group } & \multirow{2}{*}{ Dose } & \multicolumn{2}{|c|}{$\begin{array}{l}20 \text { hrs after yeast administration, } \\
\text { the anal temp. }{ }^{\circ} \mathrm{C} \text { readings are }\end{array}$} & \multirow{2}{*}{$\begin{array}{l}\text { Dose induced anal } \\
\text { temp. }{ }^{\circ} \mathrm{C} \text { decrease }\end{array}$} \\
\hline & & $\begin{array}{l}0 \text { hrs (after } \\
\text { dose admin.) }\end{array}$ & $\begin{array}{l}4 \text { hrs (after dose } \\
\text { admin.) }\end{array}$ & \\
\hline placebo & $\begin{array}{c}\text { Normal saline } 5 \\
\mathrm{ml} / \mathrm{kg}\end{array}$ & $38.01 \pm 0.29$ & $37.96 \pm 0.28$ & $0.05 \pm 0.04$ \\
\hline Standard & ASA $300 \mathrm{mg} / \mathrm{kg}$ & $37.84 \pm 0.22$ & $37.64 \pm 0.23$ & $\begin{array}{l}* 0.17 \pm 0.03 \\
\left(P=4.7 \times 10^{-4}\right)\end{array}$ \\
\hline Test & Va-SB $200 \mathrm{mg} / \mathrm{kg}$ & $37.87 \pm 0.27$ & $37.81 \pm 0.27$ & $\begin{array}{c}* 0.05 \pm 0.02 \\
\left(P=3.1 \times 10^{-3}\right)\end{array}$ \\
\hline Test & Va-SB $300 \mathrm{mg} / \mathrm{kg}$ & $37.83 \pm 0.28$ & $37.69 \pm 0.28$ & $\begin{array}{c}* 0.14 \pm 0.03 \\
\left(P=2.1 \times 10^{-3}\right)\end{array}$ \\
\hline Test & Va-SB $400 \mathrm{mg} / \mathrm{kg}$ & $37.82 \pm 0.25$ & $37.67 \pm 0.25$ & $\begin{array}{c}* 0.15 \pm 0.01 \\
\left(P=1.45 \times 10^{-3}\right)\end{array}$ \\
\hline
\end{tabular}

Data are mean \pm SEM (standard error of mean) value $(n=5)$. ${ }^{*}$ Significantly $(P \leq 0.05)$ different from placebo. 


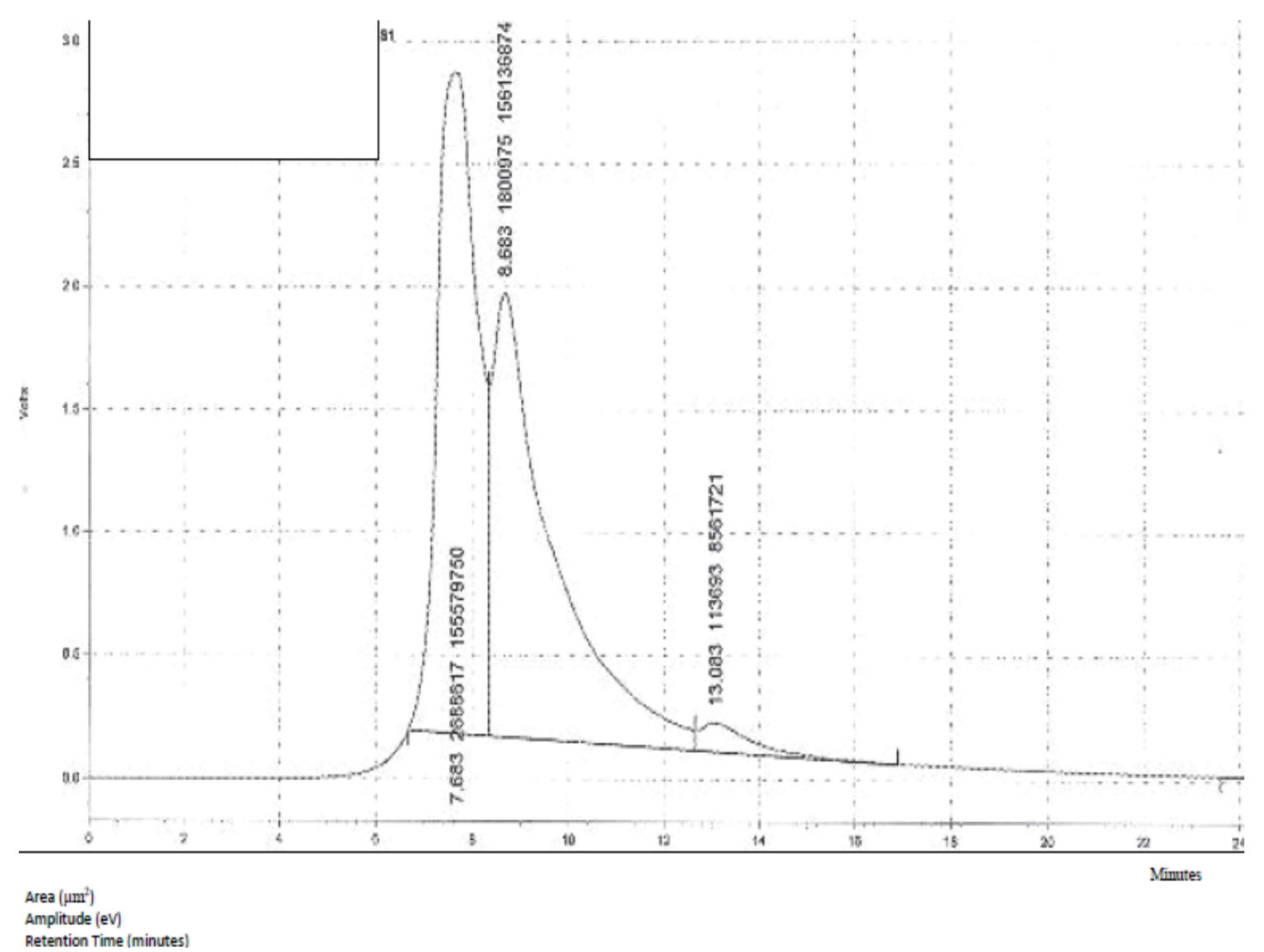

Figure 1: UV-spectrum of developed chromatogram indicating pure components and retention time.

\section{DISCUSSION}

The use of Vernonia amygdalina leaf as food has always required prior processing, leading to the loss of possible medicinal principles (Adetuyi et al., 2008). In the current study, the antipyretic properties of the leaf aqueous extract and a major anti-nutritive constituent saponin, usually lost during processing for food due to its aqueous solubility, were investigated.

In the antipyretic study, brewer's yeast was used as an exogenous stimulus to induce pyrexia, probably in a manner similar to lipopolyssacharides in laboratory animals (Walter, 2003). Such induction commonly activates the arachidonic acid pathway which is associated with increase in prostaglandin $E_{2}$ $\left(\mathrm{PGE}_{2}\right)$ (Kasper et al., 2008). The antipyretic activity data indicated that the leaf aqueous extract, crude saponin and Va-SB at the doses used, significantly $(P \leq 0.05)$ decreased the yeast induced anal temperature in the rats. Prior studies have shown that inhibiting the arachidonic acid pathway, and specifically the activity of cyclo-oxygenase, results in the reduction of $\mathrm{PgE}_{2}$ level within the hypothalamus and decrease of the associated pyrexia (David et al., 2001). This suggests that the test samples, like the reference standard, ASA possess inhibitory activity against the arachidonic acid pathway.

The leaf extract at 400 and $600 \mathrm{mg} / \mathrm{kg}$ dose levels, exhibited higher anal temperature decrease than that observed in a similar study with the root extract of the plant (Okokon and Onah, 2004). Perhaps the difference between 
the antipyretic data obtained for the crude saponin and Va-SB at similar dose levels in this study suggests that other principle(s), possessing either antipyretic or potentiating effect may be present in the crude saponin (Ramaswamy et al., 1985).

Generally, saponins are considered to be toxic with majority being powerful hemolytic in vitro. However, large doses may be needed to produce toxic effect when administered parenterally, and larger doses due to poor absorption, when administered orally. Several toxicity tests have shown that the lethal oral dose of saponins is three to one thousand times as large as the lethal intravenous dose (George, 1965). As such, toxicity to warm blooded animals is dependent on the admixture composition, concentration and route of administration (Liu and Henkel, 2002). Data obtained from previous in vivo studies using rats, mice and rabbits showed that saponins are not absorbed in the alimentary canal but hydrolyzed to their corresponding sapogenins (aglycone) and sugar by enzymatic action (Güçlü-Ustündağ and Mazza, 2007). The readily more absorbable aglycone is because of this reason, usually considered responsible for most of the associated activities with the orally administered saponins. This may explain the safety of the orally administered Vernonia amygdalina extract, crude saponin and Va-SB fraction as used in this study (George, 1965).

The use of reverse phase HPLC technique in purifying and isolating phytoprinciples obtained by crude aqueous extraction is a common practice in phytoanalysis (Cairns, 2002). This is because of the polar nature of such constituents. From the retention time obtained for the pure principles, $\mathrm{VaSB}_{1}$ exhibited the most polarity at a recovery time of $7.78 \pm 0.19$ minutes, followed by $\mathrm{VaSB}_{2}(8.76 \pm 0.16$ minutes $)$ while the least polar was $\mathrm{VaSB}_{3}$ at $13.54 \pm$ 0.87 minutes.

According to Beer-Lambert laws, the magnitude of absorption or emission by an electromagnetic active substance is directly proportional to its magnitude (Cairns, 2002;
Davidson, 2004). Absorption or emission involves the transition of electrons between orbitals. Of immense consideration in this study is the $\pi \rightarrow \pi^{*}$ transitions which requires less energy. This transition occurs at longer wave lengths which in some cases can be indicative of the relative extent of conjugation or presence of a chromophoric group by coloration (Olaniyi, 2000). Substances absorbing at this visible or near visible region of the spectrum have the tendency to exhibit characteristic color. The observed color of the pure components was milky white and agrees with this assertion for saponins (Kamperdick et al., 1992). The obtained quantitative data for these principles $\left(\mathrm{Va}-\mathrm{SB}_{1}, \mathrm{Va}-\mathrm{SB}_{2}\right.$, and $\mathrm{Va}$ $\mathrm{SB}_{3}$ ) were at a ratio of $24: 24: 1$ as shown by their relative areas of absorption. These components can be considered to be key contributors to the bioactivities associated with the saponin fraction of the leaf extract. Though the obtained chromatogram suggests their physicochemical nature, obtained data were not sufficient to show the individual structural identity.

\section{Conclusion}

In conclusion therefore, this study agrees with previous report on the antipyretic activity property of the aqueous extract of Vernonia amygdalina leaf and its saponin principle. The Va-SB fraction considered to be responsible for the antipyretic effect of the crude saponin was shown by this study to be composed of three pure principles. However, obtained data did not show the individual bioactivity contribution of these pure components. In this regard, studies to further probe the activities and elucidate the structure of these pure components will be of benefit in actualizing the ultimate value of this herb.

\section{COMPETING INTERESTS}

No competing interests exist.

\section{AUTHORS' CONTRIBUTIONS}

PCA was the principal investigator of the study. PP participated in the chromatographic and spectroscopic analysis. 
$\mathrm{JJ}$ participated in the phytochemical screening and pant identification. PM-K and IO-B participated in the animal study. MB participated in the manuscript write-up. GN supervised the analytical and animal evaluations respectively.

\section{ACKNOWLEDGEMENTS}

The authors are grateful to Professor Paul Waako of Pharmacology Department, College of Health Sciences, Makerere University Molago for his invaluable advice and input. We are also grateful to Chief. P.J Adiukwu and Ms. Mabel Ebere for their technical input; the Faculty of Medicine Ethical Committee of Mbarara University of Science \& Technology, Uganda for the review of the study protocols; the staff and management of Natural Chemotherapeutic Research Laboratories, Kampala for availing their facilities and time for this study; the entire management and staff of the University of Health and Allied Sciences, Ho Ghana where the summing up activities were carried out; and Mr. Rujumba Bright of the Animal Facility, Mbarara University of Science and Technology, Uganda for his commitment during the animal study.

\section{REFERENCES}

Adetuyi FO, Ajala L, Dada IBO. 2008. Effect of processing methods on the chemical composition and antioxidants potentials of Structium sparejanophora (EwuroOdo) and Vernonia amygdalina (Ewuro). Nig. Food J., 26(1): 133-140. DOI: http://dx.doi.org/10.4314/nifoj.v26i1.474 31.

Adiukwu CP, Agaba A, Nambatya G. 2011. Pharmacognostic, antiplasmodial and antipyretic evaluation of the aqueous extract of Vernonia amygdalina leaf. Int. J. Biol. Chem. Sci., 5(2): 709-716. DOI: http://dx.doi.org/10.4314/ijbcs.v5i2.7213 4.

Adiukwu PC, Kayanja FIB, Nambatya GK. 2013. Antipyretic and antinociceptive properties of the aqueous extract and saponin from an edible vegetable:
Vernonia amygdalina leaf. AJFAND, 3(2): 7587-7606. DOI: http://dx.doi.org/10.4314/ajfand.v3i2.11 135.

Bonsi MLK, Osuji PO, Tuah AK, Umunna NN. 1995. Vernonia amygdalina as a supplement to teff straw fed to Ethiopian menz sheep. Agroforestry Systems, 31(3): 229-241. DOI: https://doi.org/ 10.1016/0377-8401(94)00702-B.

Cairns D. 2002. Analytical Spectroscopy. In Essentials of Pharmaceutical Chemistry. Pharmaceutical Press: London; 77-96.

David M, Aronoff MD, Eric G, Neilson MD. 2001. Antipyretics: Mechanisms of action and clinical use in fever suppression. AJM, 111(4): 304-315.

Davidson AG. 2004. Ultraviolet-visible absorption spectrometry. In Practical pharmaceutical chemistry $\left(4^{\text {th }}\right.$ edn, Part II), Beckett AH, Stenlake JB (eds). CBS: New Delhi; 275-337.

George AJ. 1965. Legal status and toxicity of saponins. Food Chem. Toxicol., 3: 85-91. DOI: https://doi.org/10.1016/0308-8146 (81)90019-4.

Güçlü-Ustündağ O, Mazza G. 2007. Saponins: properties, applications and processing. Criti. Rev. Food Sci. Nutrit., 47(3): 23158. DOI: https://doi.org/10. 1080/10408390600698197.

Harborne JB. 1973. Phytochemical Methods. Chapman and Hall: London; 113.

Hostettmann M, Marston A. 1986. High Pressure Liquid Chromatography: Preparative Chromatography Technigues. Springer-Verlag: New York, Heidelberg, Berlin; 56-61.

Izevbigie EB. 2005. Phytochemotherapy for Cancer. United States Patent: 6,849,604; February 1.

Kamperdick C, Breitamaier E, Radloff A. 1992. A new steroid from $V$. amygdalina del. (Compositeae). J. Prakt. Chem., 334: 425-428. DOI: https//doi.org/10. 1002/prac. 19923340509.

Kasper DL, Fauci AS, Longo DL, Braunwald E. 2008. Diseases of the spinal cord. In Harrison's Principles of Internal 
Medicine $\left(17^{\text {th }}\right.$ edn), Hauser SL, Ropper AH (eds). McGraw-Hill Professional: New York; 117-121.

Liu J, Henkel T. 2002. Traditional Chinese Medicine (TCM): are polyphenols and saponins the key ingredients triggering biological activities? Curr. Med. Chem., 9: 1483-1485. DOI: https://doi.org/10. 2174/0929867023369709.

NIH (National Institute of Health). 1978. Guide for the Care and Use of Laboratory Animals. NIH publication No. 83-23. National Institute of Health, Bethesda, MD.

Nwaoguikpe RN. 2010. The effect of extract of bitter leaf (Vernonia amygdalina) on blood glucose levels of diabetic rats. Int. J. Biol. Chem. Sci., 4(3): 721-729. DOI: http://dx.doi.org/10.4314/ijbcs.v4i3.6050 0 .

Obadoni BO, Ochuko PO. 2001. Phytochemical studies and comparative efficacy of the crude extracts of some homeostatic plants in Edo and Delta States of Nigeria. Global J. Pure and Appl. Sci., 8: 203-208. DOI: http://dx.doi.org/10.4314/gjpas.v8i2.160 33.

Okokon JE, Onah MI. 2004. Pharmacological studies on root extract of Vernonia amygdalina. Nigeria J. Prod. \& Med., 8: 59-61.

Olaniyi AA. 2000. Spectroscopic methods. In Principle of Drug Quality Assurance and Pharmaceutical $\left(3^{\text {rd }}\right.$ edn). Olaniyi AA (ed). Mosuro: Ibadan; 213-225.

Owoeye O, Yousuf S, Akhtar MN, Qamar K, Dar A, Farombi EO, Onwuka SK, Choudhary MI. 2010. Another anticancer elemanolide from Vernonia amygdalina del. Int. J. Biol. Chem. Sci., 4(1): 542-
550. DOI: http://dx.doi.org/10.4314/ ijbcs.v4i1.54250.

Patrice C, Laura JG, Jacqui T, Kamlesh K, Melanie JD. 2010. Fruit and Vegetable Intake and Incidence of Type 2 diabetes mellitus: Systematic review and metaanalysis. $B M J$, 341: 4229. DOI: https://doi.org/10.1136/bmj.c4229.

Ramaswamy S, Pillai NP, Gopalkrishnan V, Parmar NS and MN Ghosh. 1985. Analgesic effect of O-( $($ hydroxy ethyl) Rutoside in mice. Indian J. Exp. Biol., 23: 219-20.

Ridout CL, Price KR, DuPont MS, Parker ML, Fenwick GR. 1991. Quinoa saponins: Analysis and preliminary investigations into the effect of reduction by processing. J. Sci. food Agri., 54: 165-176. DOI: doi/10.1002/jsfa. 2740540202.

Shi J, Konesh A, Yeung D, Kakuda Y, Mittal G, Jiang Y. 2004. Saponins from edible legumes: chemistry, processing, and health benefits. J. Med. Food, 7(1): 6778. DOI: https://doi.org/10.1089/ 109662004322984734.

Singh J. 2008. Maceration, percolation and infusion techniques for extraction of medicinal and aromatic plants. In Extraction Technologies for Medicinal and Aromatic Plants, Handa SS, Khanuja PS, Longo G, Rakesh DD (Eds). ICS-UNIDO; Trieste; 67-82.

Stil WC, Kahn M, Mitra A. 1978. Rapid chromatographic technique for preparative separations with moderate resolution. J. Org. Chem., 43: 29232925. DOI: https://doi.org/10.1021/ jo00408a041

Walter F. 2003. Medical Physiology: A Cellular and Molecular Approach. Elsevier/Saunders; 1300. 